\title{
Comparative analysis of options for project financing of energy development based on renewable sources
}

\author{
$O . V$. Luskatova $^{1, *}, M . V$. Roberts $^{2}$, and $E . N$. Dolzhenko ${ }^{3}$ \\ ${ }^{1}$ Vladimir Branch of Russian Presidential Academy of National Economy and Public Administration, Vladimir, Russia \\ ${ }^{2}$ Vladimir State University, Vladimir. Russia \\ ${ }^{3}$ Norilsk State Industrial Institute, Norilsk, Russia
}

\begin{abstract}
The features of the dielectric rod defects and the rod-electrod defects of polymer insulators were investigated by using the developed complex method of contactless remote diagnostics of high-voltage insulators health, which includes the initial detection of local areas with elevated electric field gradients as well as measurement of a set of partial discharges characteristics. The radiation of extra-large partial discharges was detected and partial discharges features were investigated. According to the measurement results, a diagram was constructed for the electro-physical processes that accompany the emission of extralarge partial discharges; and the reasons for their occurrence were established.
\end{abstract}

\section{Introduction}

A variety of organic polymers have been used as The development of the Russian economy currently depends on the modernization of the country's energy infrastructure, which is carried out taking into account the providing of environmental and energy security. The implementation of generating capacity projects based on renewable energy sources is facing problems of sustainable and affordable financing. In the country's power industry, the developed power of the generating objects operating through the use of renewable energy sources, which include wind, solar power plants (WPP, SPP) and small hydroelectric power stations, in 2017 amounted to $0.064 \%$, and in 2018 increased to $0.09 \%$ [1]. The State program of the Russian Federation "Energy Development" suggests increasing this indicator up to $4.5 \%$ in 2024 [2], which can only be achieved if there is an optimized investment scheme for projects of creating alternative energy facilities.

The world experience in the development of energy using renewable sources shows that government state funds are not enough [3]. The low level of use of alternative power plants rated capacity makes the attraction of the private capital difficult. Thanks to the modern innovative technologies, the cost of producing 1 $\mathrm{kWh}$ of electricity generated from renewable resources become comparable to the indicators of traditional types of power plants. But in 2018 the amount of installed renewable power generation capacity reached $18.3 \%$ for WPP and $14.6 \%$ - for SPP, which was significantly lower than even the average indicator for the United Energy System (UES) of Russia - 50.4\% [1]. Private investors are financing the construction and reconstruction of such facilities on the terms of venture capital allocation. Synthesis of government and private sources is manifested in the use of various types of project financing [4].

Searching the investors in the Russian realities happens under sanctions' restrictions. It is associated with the need to select the best-designed financial instruments for cash inflows or clarify the conditions for participation in the contract. In Russia for the capitalintensive innovative technologies, various forms of project financing are used: with the involvement of bank capital, under the program "Project Finance Factory", the creation of special project companies (SPC) that have the opportunity to use territorial preferential terms [5]. The practice of this type of investment in the field of alternative energy sources is only being formed, which indicates the relevance of the topic under consideration.

The aim of the research was to study and compare possible options for investing in alternative energy projects with various financing schemes.

\section{Instruments and methods}

The world practice of project financing identifies three main types: bank, corporate and with the participation of the government [6]. In case of bank project financing the main source of investment is a credit institution. Distinctions of conditions of assignment consist in extent of acceptance by bank on itself risks on implementation of the project. They can be maximized in case of signing a contract without recourse to the borrower, or minimal in a contract with full recourse to the borrower.

Corporate project financing assumes that the project is sponsored by a private company or a consortium, and the project company being created is the only borrower for the attracted resources.

\footnotetext{
*Corresponding author: oluskatova@mail.ru
} 
Public-private partnership (PPP) is deployed during the implementation of socially significant projects. The budget structures create SPC, finance most of the project and guarantee the fulfillment of obligations, which facilitates the attraction of private sector capital. The participation of corporate capital varies according to the accepted financing scheme, which is fixed as a type of a concession agreement. There are the following types of financial contracts:

- BOO (built - own - operate) - a special project company develops and implements a project for the purpose of further exploitation and ownership.

- BOOT (built - own - operate - transfer) - the participant agrees to develop and implement the project, then receives it in ownership and manages it for a long period of time on the basis of contractual agreements, and then transfers the object of exploitation into the ownership of another participant (government, corporation), with the right to receive dividends; The cost of the transfer of the object may be market, fixed or zero.

- BOT (built - operate - transfer) - the participant agrees to develop and implement the project, gets the object of operation into management for a long period of time and then transfers it to the ownership of another participant (government, corporation).

- ROT (refurbish - operate - transfer) - a participant acquires and reconstructs an object that has already been created, manages it for a long period of time, and then transfers the object to the ownership of another participant (government, corporation) [7].

Distinctions of concession agreements provide necessary degree of profitability and minimize risk taking into account branch specifics of the project. For example, to reduce risks in energy projects SPC signs a contract, on the basis of which products manufactured within the framework of the project will be guaranteed to be sold to the buyer on previously agreed terms (a take or pay contract).

For the purpose of minimization of risks the project agreements include auxiliary contracts. For example, Engineering, procurement and construction (EPC) contract or Design, procurement and construction (DPC) contract, which assume that the uniform company performs all functions of the construction as general contractor, general designer, general supplier, attracting subcontractors only for some types of specialized works and completely being responsible for their results. In energy projects, this contract determines the order of execution of works by the contractor at a certain price and with completion by a certain date. The permits which are necessary both at the project construction stage (related to the assessment of the environmental impact of the project activities, permission for construction and operation) and at the operation stage (investment permit for foreign investors) are considered to be the important part of the concession agreement. The government support agreement can provide various types of support, such as procurement guarantees or tax incentives for investment in a project [8].

According to the results of the analysis, the market for project financing $(\mathrm{PF})$ of renewable energy sources in
Russia can be assessed as undeveloped. In 2013 - 2019 there were only 2 banking PF transactions in the amount of about \$ 361 million, and no project bonds were issued. Both transactions took place in the hydropower sector (Saratovskaya HPP, Beloporozhskaya HPP-1, Beloporozhskaya HPP-2). The main companies operating with renewables in Russia, such as "Nord Hydro", "Rosnano", "Fortum", "Hevel", "T Plus", have a long-term project program which includes the deployment of the project finance (PF) mechanism.

The project on the construction of the Beloporozhsk HPPs solves the problem of the power shortage and fixes the satisfactory level of electricity costs for consumers. This project was the first in Russia to receive funding from the BRICS New Development Bank.

The Ulyanovsk region is currently positioning itself as the territory of a wind power cluster. During the implementation, it is planned to introduce seven wind farms with a total capacity of about $250 \mathrm{MW}$ by 2024 , and by 2030 almost a third of the generated electricity will be produced on the basis of renewable energy. In 2018 the first industrial wind farm is put into operation in the region, it includes 14 wind towers with a general power of $35 \mathrm{MW}$. The project is realized by the Finnish company "Fortum" and the Russian concern "Rosnano". The central element of the cluster was the first in Russia plant producing fiberglass blades for wind turbines of the Vestas company, which in 2019 reached the design capacity of 330 blades per year. This company ensures the independence of wind energy projects in Russia from political sanctions.

Among the leading regions in solar power generation, there are the Astrakhan region (by 2019, the installed capacity of the SPP is $135 \mathrm{MW}$ ), the Saratov region $(100 \mathrm{MW})$, the Orenburg region $(90 \mathrm{MW})$, the Zabaykalsky region (30 MW) [9].

According to the research of the International Renewable Energy Agency (IRENA), the Russian Federation has the greatest potential in the world for the development of wind energy [10]. The insolation map of the country's regions indicates a significant number of regions suitable for the development of solar energy, as their indicators are comparable with the north of Spain and the south of Germany - the leading countries in this sector of renewable energy [11]. At the same time, a considerable number of regions favorable for the development of solar energy are energy deficient.

In February, 2018 the Government of the Russian Federation adopted Resolution No. 158 "On the program "Project Financing Factory", which regulates subsidies from the Federal budget in the form of reimbursement to Vnesheconombank (VEB), as an authorized bank, for providing loans and borrowings in the framework of the Program, as well as state guarantees of the Russian Federation for bonded loans attracted by a specialized project financing company [12]. "Implementing the best available technologies and reducing the negative impact on the environment" is considered to be one of the main direction for financing in the frame of the program [13]. In 2018, the budget allocated 828 million rubles for the implementation of this Program. Also, the draft of Russia's energy strategy for the period up to 2035 
provides an economic measure to support renewablesubsidizing interest rates on loans to organizations deploying renewable energy technologies [14].

\section{Research results and discussion}

In Russian practice, banking PF (especially syndicated lending) is most common, while the use of PPP schemes with various types of concession agreements and the issue of project bonds is practically not used, despite the accumulated foreign experience of effective use of these tools in the implementation of regional infrastructure projects.

The existing mechanism for issuing state guarantees on loans for investment projects of enterprises is inefficient, the result is an excessive increase of the government debt on contingent liabilities of the Federal budget. In the case of paid government guarantees administrative costs can be reduced, and the savings can be spent on issuing state guarantees for projects implemented under the PF scheme. The private sector will get the government support such as the decrease in rates on the raised funds. The size of the rate paid for the provided guarantee may depend on the type of borrower, the size of the obligations he undertakes and the level of risk (proceeding from assessment of probability of execution of a guarantee) and may be $0.5-1 \%$.

In the interest of developing project financing of alternative energy, in the authors' opinion, the implementation of the following proposals is necessary:

- Further development of the state support measures for project financing, including financial and tax mechanisms (privileges on payment of the customs duty on the equipment and the property tax, assistance when granting the land plots for the project and creation of necessary infrastructure);

- Active participation of responsible government agencies in attracting to projects the working in Russia multilateral development banks (VEB, EDB, IIB, BRICS New Development Bank, etc.). Their investments in renewable energy projects allow to reduce the cost of financing;

- Reorganization of the existing mechanism for providing the state guarantees in the implementation of investment projects in the sphere of alternative energy on the territory of Russia, realized according to the Program "Project Financing Factory". The deployment of the paid guarantees' system depends on the risk level of the project (for example, the mechanism of the OECD member countries).

- Improving support mechanisms for the renewable energy industry in the framework of energy and industrial policies. Nowadays the mechanism for competitive selection of projects is based on the smallest CAPEX. The winners sign the power capacity supply contracts with the use of renewable energy sources (the mechanism is supposed to be prolonged till 2035). In this situation the burden on large industrial consumers has increased as return of investments is shifted to consumers of the wholesale market.
As an example of implementation, we have considered a project for the construction of solar power plants (SPP) in the Saratov region. The volume of necessary investments is 9900.27 million rubles. The company's equity in the project amounts to $2,475.07$ million rubles. The amount of required borrowed funds is 7425.20 million rubles. The plan includes the construction of three SPP with the installed capacity of $20 \mathrm{MW}$, two - of $15 \mathrm{MW}$ each and one - $10 \mathrm{MW}$, the total capacity of six objects will be $100 \mathrm{MW}$, which is comparable to the level of SPP currently used in the region [15].

The construction costs of the plants (construction and installation, commissioning, supervision) will amount to 748.8 million rubles. The cost of heterostructure modules is 4,614.72 million rubles. The volume of investments in the infrastructure of the plants (supporting structures, network equipment, cables and other equipment) - 2490 million rubles. The costs for the development of the project, working documentation, delivery of equipment and panels and connection to electric networks will amount to 2046.75 million rubles. The expected time of commissioning of facilities is 2020. The price of electricity in the calculations is fixed and amounts to $29.48 \mathrm{rubles} / \mathrm{kWh}$, the output reaches $100 \mathrm{GWh} /$ year.

Given the lack of own funds of "Hevel" GC, the project can be implemented using the following financing options:

- Attraction of loan capital in the form of project financing from a commercial bank (a syndicated loan of 7425.2 million rubles at $12.5 \%$ per annum, a period of 10 years);

- Attraction of borrowed capital under the existing program "Project Financing Factory" (Vnesheconombank lends 4,455.12 million rubles at $10.3 \%$ per annum, commercial banks - 2,970.08 million rubles at $12.5 \%$ per annum, for 10 years);

- Attraction of borrowed capital in the form of project financing, taking into account the developed proposals (getting a loan from VEB in the amount of $4,455.12$ million rubles at $10.3 \%$ per annum and development banks (NDB BRICS / ABII) in the amount of $2,970.08$ million rubles. at $2.5 \%$ per annum and the cost of obtaining a guarantee from VEB is $1 \%$, the term is 10 years).

Table 1. Comparison of indicators of project investments' efficiency by options.

\begin{tabular}{|c|c|c|c|c|}
\hline \multirow[b]{2}{*}{ Indicator } & \multicolumn{3}{|c|}{ Value } & \multirow{2}{*}{$\begin{array}{l}\text { Meas. } \\
\text { Unit }\end{array}$} \\
\hline & $\begin{array}{c}\text { Option } \\
\text { I }\end{array}$ & $\begin{array}{l}\text { Option } \\
\text { II }\end{array}$ & $\begin{array}{l}\text { Option } \\
\text { III }\end{array}$ & \\
\hline NPV & $\begin{array}{c}2633.7 \\
3 \\
\end{array}$ & 2677.53 & 3040.82 & $\begin{array}{l}\text { million } \\
\text { rubles }\end{array}$ \\
\hline $\begin{array}{l}\text { Payback } \\
\text { period }\end{array}$ & 13 & 13 & 13 & years \\
\hline IRR & 14.38 & 14.46 & 15.10 & $\%$ \\
\hline PI & 1.06 & 1.08 & 1.23 & pcs \\
\hline $\begin{array}{l}\text { Payments to } \\
\text { the budget }\end{array}$ & 446.52 & 448.03 & 427.32 & $\begin{array}{l}\text { million } \\
\text { rubles }\end{array}$ \\
\hline
\end{tabular}


The comparison of the obtained financing options for the SPP construction project will make it possible to select the optimal one, based on the maximum value of the net present value (NPV) indicator (table 1). The analysis was carried out without taking into account restrictions on equity, which makes it possible to estimate its overall investment attractiveness.

The criterion for choosing the best option for financing the project is the maximum value of the net present value: NPV received in option III is 1.14 times higher than that obtained with option II, and 1.15 times with I. If "Hevel-Saratov" Group of Companies gets project financing in accordance with the developed proposals, the expected payback period of the project is 13 years, PI - 1.23. The NPV of the project will be 3,040.82 - 3,054.09 million rubles, IRR - 15.10 $15.13 \%$, and payments to the budget $-427.32-427.78$ million rubles.

According to the results of cash flow calculations, the project is attractive, as criteria of efficiency are maintained: NPV is positive, IRR exceeds the discount rate, the payback period value is also in a satisfactory range of values.

\section{Conclusions}

The problems of the alternative energy development in the Russian Federation are based on insufficient funding from both the government and private investors. For the solution of objectives, the project financing options are used, but their development in the electric power industry is at a low level.

The paper presents the types of PF that optimally takes into account the industry peculiarities of generating capacity based on renewable energy sources. The options of schemes for investing a specific project of providing energy of SPP in the Saratov region are considered. This will allow to provide up to a third the region with electrical energy derived from heterostructural models of PV batteries.

A financing option that combines the use of credit sources of authorized development banks (NDB BRICS / ABII) and a set of government support measures, including tax breaks and government guarantees, is recognized as the most compliant to investors. The use of this option of project financing of the construction of solar power plants demonstrates the greatest efficiency relative to other alternatives with the available resources.

\section{References}

[1] Ministry of Energy Main characteristics of the Russian power industry Moscow URL: https://minenergo.gov.ru/node/532 (2019)

[2] Ministry of Energy Order of the Ministry of Energy of the Russian Federation 174, "About the Approval of the Scheme and Program of Development of the United Energy System of Russia for 2019-2025" Moscow URL: https://minenergo.gov.ru/node/14828 (2019)
[3] B.Z.E. Cedrick and W. Long Investment Motivation in Renewable Energy: A PPP Approach J Energy Procedia 115, 229-38 (2017)

[4] V.I. Bushukina, Funding Renewable-Energy Investment Projects Bulletin of the South Ural State University Ser Power Engineering 19(1), 50-57 (2019)

[5] E.V. Gavrichenko, O.V. Luskatova, and M.V. Roberts, 2018 The industry practice of project financing News of higher education institutions. Technology of the textile industry 5(377), 5-10

[6] The World Bank Financing Renewable Energy. Options for Developing Financing Instruments Using Public Funds 50 URL: http://siteresources.worldbank.org/EXTENERGY2/Reso urces/SREP financing instruments sk clean2 FINAL FOR PRINTING.pdf (2011)

[7] I.A. Trushina, Studying of classification signs of project financing J Simvol nauki 4, 159-63 (2017)

[8] A.V. Kazansky, Risks of project financing and methods of their overcoming in the Russian projects J Problems of modern economy 1, 139-43 (2015)

[9] Alternative energy Moscow URL: https://neftegaz.ru/news/Alternative-energy (2019)

[10] IRENA REmap 2030 Renewable Energy Prospects for Russian Federation Working paper IRENA Abu Dhabi URL: www.irena.org/remap (2017)

[11] Hevel Solar energy Moscow URL: http://www.hevelsolar.com/solar/faq/\#a1 (2018)

[12] Resolution of the Government of the Russian Federation from 15.02.2018 158, (as amended on 06.06.2018) "On the program "Project Financing Factory" URL: http://ivo.garant.ru/\#/document/71881806/paragraph/1:2

[13] Resolution of the Government of the Russian Federation from 06.06.2018 № 654, “About Government guarantee of the Russian Federation on the bond issues attracted by "Specialized Society of Project Financing Factory of Project Financing" limited liability company and modification of the Project Financing Factory program

URL: http://www.garant.ru/products/ipo/prime/doc/71862918/ \#ixzz5XbZyrLJC

[14] Ministry of Energy Draft of the Energy Strategy of Russia until 2035 Moscow URL: https://minenergo.gov.ru/system/downloadpdf/1920/69055 (2017)

[15] T.S. Dupina, and M.V. Roberts, Trends in the development of project financing in modern conditions Economy and service: from theory to practice: Coll. scientific tr. Vladimir 110-17 (2017) 